ORIGINAL ARTICLE

\title{
Tourniquets in the Era of "Stop the Bleed"-Are Simple Pressure Maneuvers Being Bypassed for Tourniquets in Non-arterial Bleeding?
}

\author{
William Rothstein ${ }^{1}$, Kristine Kenning ${ }^{2}$, Karen Shipman ${ }^{3}$, Rob Lawrence ${ }^{4}$, Alan Rossi ${ }^{5}$, Paula Ferrada ${ }^{6}$, Michel Aboutanos ${ }^{7}$, \\ Edgar Rodas 8
}

\begin{abstract}
Aim: Tourniquets are a well-studied method of temporary hemostasis for life-threatening bleeding. Previous studies place the rate of true arterial injuries among applied tourniquets in civilian populations between $44 \%$ and $70.1 \%$.

Materials and methods: We conducted a single center, retrospective, case-control study of all patients with prehospital applied tourniquet between May 2016 and November 2017. Criteria for true arterial injury were traumatic amputation or arterial injury requiring immediate surgery. We pooled reported civilian data to be utilized as a reference population.

Results: In an 18-month period, 66 patients presented with tourniquets. True arterial injury existed in $36 \%$ vs $53 \%$ in the reference population (chi square $=7.3, p=0.0068)$. There was no significant difference between blunt vs penetrating mechanism $(35 \%$ vs $37 \%, p=0.85)$. Gun-shot wounds (GSW) were more likely to have no arterial injury than all other injury types ( $81 \%$ vs $56 \%, p=0.046$, OR $=3.4$ ). There was no significant difference in tourniquet application between paramedics and other first responders ( $74 \%$ vs $75 \%, p=0.48$ ).

Conclusion: Injury type appears to be a factor; in patients with a tourniquet, those with a GSW were 3.4 times as likely to have no arterial injury as other injury types. This data reflects a high frequency of prehospital tourniquet application without arterial injury. Multi-institutional, prospective studies are necessary to evaluate tourniquet utilization.
\end{abstract}

Keywords: Emergency medical services, Extremity trauma, Hemorrhage, Prehospital, Tourniquet.

Panamerican Journal of Trauma, Critical Care \& Emergency Surgery (2019): 10.5005/jp-journals-10030-1237

\section{Abstrato}

Objetivo: Torniquetes são um método bem estudado de hemostasia temporária para sangramento com risco de vida. Estudos anteriores colocam a taxa de lesões arteriais verdadeiras entre torniquetes aplicados em populações civis entre $44 \%$ e $70,1 \%$.

Materiais e métodos: Foi realizado um estudo único, retrospectivo, caso-controle, de todos os pacientes com torniquete pré-hospitalar aplicado entre maio de 2016 e novembro de 2017. Os critérios para lesão arterial verdadeira foram amputação traumática ou lesão arterial requerendo cirurgia imediata. Agrupamos os dados civis relatados para serem utilizados como população de referência.

Resultados: Em um período de 18 meses, 66 pacientes apresentaram torniquetes. A lesão arterial verdadeira existia em $36 \%$ vs $53 \%$ na população de referência (qui quadrado $=7,3, p=0,0068$ ). Não houve diferença significativa entre o mecanismo de penetração e penetração (35\% vs $37 \%$, $p=0,85$ ). As feridas por arma de fogo (GSW) foram mais propensas a não ter lesão arterial do que todos os outros tipos de lesão (81\% vs $56 \%$, $p=0,046, \mathrm{OR}=3,4)$. Não houve diferença significativa na aplicação de torniquete entre paramédicos e outros socorristas $(74 \%$ vs $75 \%, p=0,48)$.

Conclusões: $\mathrm{O}$ tipo de lesão parece ser um fator; em pacientes com torniquete, aqueles com GSW tinham 3,4 vezes mais probabilidade de não ter lesão arterial do que outros tipos de lesão. Esses dados refletem uma alta frequência de aplicação do torniquete pré-hospitalar sem lesão arterial. Estudos prospectivos e multi-institucionais são necessários para avaliar a utilização do torniquete.

Significado clínico: Muitos torniquetes pré-hospitalares podem não ser necessários, com potencial incerto para danos.

Palabras clave: Hemorragia, Pré-hospitalar, Serviços médicos de emergência, Torniquete, Traumatismo por extremidades.

\section{BACKGROUND}

Hemorrhage control is a cornerstone of trauma care. One of the possible etiologies of hemorrhagic shock in trauma is severe extremity injury. Data acquired in modern military campaigns demonstrate that battlefield tourniquet application improves survival from major extremity injury in combat trauma. ${ }^{1-3}$ Tourniquets save lives. Additionally, major review articles reported no tourniquet-associated limb loss. Based on the military experience, there is low morbidity when a tourniquet is properly used. ${ }^{2,3}$ In light of these results, investigators turned to assessing the utility of prehospital tourniquet application in civilian trauma. Both single-center and multicenter retrospective
1,2Department of Surgery, Virginia Commonwealth University Health System, Richmond, Virginia, USA

${ }^{3,5-8}$ Division of Acute Care Surgical Services, Department of Surgery, Virginia Commonwealth University Health System, Richmond, Virginia, USA

${ }^{4}$ Richmond Ambulance Authority, Richmond, Virginia, USA

Corresponding Author: Edgar Rodas, Division of Acute Care Surgical Services, Department of Surgery, Virginia Commonwealth University Health System, Richmond, Virginia, USA, Phone: +1 804-240-5604, e-mail: edgar.rodas@vcuhealth.org 
How to cite this article: Rothstein W, Kenning K, et al. Tourniquets in the Era of "Stop the Bleed"-Are Simple Pressure Maneuvers Being Bypassed for Tourniquets in Non-arterial Bleeding? Panam J Trauma Crit Care Emerg Surg 2019;8(1):56-60.

Presented at: XXXI Panamerican Congress of Trauma, Critical Care \& Emergency Surgery, Cartagena, Colombia, August 14-17, 2018.

Source of support: Nil

Conflict of interest: None

reviews demonstrated minimal morbidity that was comparable to the military experience. ${ }^{4,5}$ These favorable results have led to the implementation of prehospital tourniquet initiatives throughout the United States. Interestingly, the authors involved in the initial military studies have cautioned about broad implementation that is not necessarily supported by high-quality evidence. ${ }^{6}$

Stop the Bleed is a national campaign that teaches bleeding control methods to the public. ${ }^{7}$ A focus of the campaign is the education of bystanders so that bystanders can become immediate responders. Stop the Bleed instructs the following bleeding control techniques: the application of direct pressure, the packing of wounds, and the placement of tourniquets. Tourniquets are used for extremity injuries with life-threatening bleeding, especially from true arterial injuries, that cannot be controlled with direct pressure. The rate of true arterial injuries with prehospital tourniquets in place has been previously reported to be $44-70.1 \%$. ${ }^{4,5}$ Anecdotal evidence from our institution suggests that the rate of unindicated tourniquet application (i.e., non-arterial injury) has increased. Our aim in this study is to evaluate if tourniquet use in non-arterial injury has increased with the more widespread adoption of prehospital tourniquet use. Depending on the results, the previous understanding of tourniquet safety and efficacy in civilian trauma may need to be revisited.

\section{Methods}

After obtaining approval from the institutional review board, we retrospectively reviewed our trauma database for all adult patients (age $\geq 18$ years old) who presented to the Emergency Department as trauma activations with prehospital tourniquets from May 2016 to November 2017. Data collected included age, comorbidities, injury mechanism, tourniquet application time, Emergency Department arrival time, type of provider placing tourniquet (i.e., bystander, law enforcement, paramedic, emergency medical technician, physician, etc.), and tourniquet location.

Chart review was conducted to record vascular findings in the trauma bay. These included the following findings that were recorded before and after the removal of the tourniquet: presence of pulsatile bleeding, pulse evaluation, sensory exam findings, and motor exam findings. In addition to their mechanism, injuries were categorized as gunshot wound (GSW), penetrating wound other than GSW, laceration or soft tissue avulsion, open fracture, digital amputation (partial or complete), partial extremity amputation, and complete extremity amputation. Imaging studies to delineate vascular injury were recorded, including ultrasonography with Doppler flow, computed tomography (CT), CT with contrast angiography (CTA), and catheter angiography. All invasive interventions related to vascular injury were recorded, including percutaneous embolization, endovascular stenting, open arterial repair, and amputation.
Tourniquets were considered indicated if arterial injury was diagnosed on exam or imaging, if emergency invasive intervention was required for arterial injury, or if the patient presented with a complete extremity amputation. Data were analyzed using JMP (SAS Institute, Cary, NC). Civilian data previously reported by Scerbo et al. and Inaba et al. were pooled as a reference population. Frequencies were compared using a Chi-squared test. A $p$ value $<0.05$ was considered significant.

\section{Results}

A total of 66 patients with prehospital tourniquets presented as trauma activations between May 2016 and November 2017. The average age was 38.4 years old. Injury mechanisms were evenly split between blunt and penetrating, with 36 penetrating injuries (55\%) and 30 blunt injuries (45\%). Of penetrating injuries, GSWs were the most frequent ( $n=21)$, followed by lacerations $(n=13)$ and penetrating stab injuries $(n=2)$. The full breakdown of injury mechanisms can be viewed in Table 1.

The most common injury category was laceration or soft tissue avulsion, as seen in Table 2. One injury with a mechanism of GSW was considered an open fracture for the purpose of injury categorization.

By far, the most common providers placing tourniquets were paramedics and emergency medical technicians $(n=34)$. This was followed by police personnel $(n=8)$, Emergency department personnel $(n=6)$, and bystanders $(n=3)$. In nine patients, the medical record did not explicitly state which provider placed the tourniquet, or the record was unavailable. One patient self applied a tourniquet.

The number of indicated tourniquets, as defined by clinical exam findings consistent with arterial injury (diminished pulses, pulsatile bleeding, complete amputation), imaging findings of arterial injury, or need for invasive intervention, was 24 (36.4\%). All of these patients underwent invasive intervention with five undergoing extremity amputation, 15 undergoing open operative repair or bypass, and three undergoing percutaneous intervention. One patient had an open operative repair that was

Table 1: Injury mechanism and frequency

\begin{tabular}{lcc}
\hline Mechanism & $N$ & \% oftotal \\
\hline GSW & 21 & 31.8 \\
Laceration & 13 & 19.7 \\
Motor vehicle collision & 8 & 12.1 \\
Machine/industrial & 7 & 10.6 \\
Motorcycle collision & 5 & 7.6 \\
Pedestrian struck & 4 & 6.1 \\
Fall & 3 & 4.5 \\
Moped collision & 2 & 3 \\
Penetrating stab & 2 & 3 \\
\hline
\end{tabular}

Table 2: Injury category and frequency

\begin{tabular}{lcc}
\hline Category & $N$ & \% of total \\
\hline Laceration or soft tissue avulsion & 21 & 31.8 \\
GSW & 20 & 30.3 \\
Open fracture & 14 & 21.2 \\
Partial amputation & 5 & 7.6 \\
Digital amputation & 3 & 4.5 \\
Penetrating non-GSW & 2 & 3 \\
Complete amputation & 1 & 1.5 \\
\hline
\end{tabular}


subsequently revised to an amputation. Traumatic upper extremity digital amputation, and subsequent related surgical care was not considered an indication for tourniquet application.

In this case series, 40 patients (63.6\%) presenting with a prehospital tourniquet did not have a major arterial injury. The difference in true arterial injury in our population (36.4\%) compared with the reference population from previous reports (53\%) is statistically significant (Chi-square $=7.3, p=0.0068$ ). There was no significant difference in frequency of true arterial injury between blunt and penetrating mechanisms (35 vs $37 \%, p=0.85$ ). GSWs presenting with prehospital tourniquets were more likely to have no arterial injury compared to all other injury types ( 81 vs $56 \%, p=0.046$ ), with an odds ratio of 3.4. There were no significant differences between provider types regarding placing unindicated tourniquets. Paramedics did not have a significantly higher rate of placing unindicated tourniquets than other providers (74 vs $75 \%, p=0.48$ ).

\section{Discussion}

Tourniquet placement is not without risk. Placement risks temporary or permanent neurological deficits as well as limb ischemia, and the risks increase with longer tourniquet times. ${ }^{3,8}$ Dangerous hemodynamic consequences from reperfusion must also be considered. ${ }^{9}$ Historical parallels may be drawn to the use of the now-defunct medical anti-shock trousers (MAST) device. ${ }^{10}$ After a period of enthusiastic adoption, multiple studies reevaluating MAST devices in disaster settings revealed questionable benefit and significant risks of harm..$^{11-13}$ While civilian extremity tourniquet use likely has a stronger evidentiary foundation than the MAST device, contemporary studies suggest a high rate of inappropriate use. ${ }^{8}$ Our study adds to this body of evidence.

In our single-center retrospective analysis, $63.6 \%$ of patients presenting with a prehospital tourniquet did not have an arterial injury. This is a higher rate than previously reported civilian data and suggests that the safety and efficacy of civilian tourniquet use needs to be continuously reappraised in the age of "Stop the Bleed". ${ }^{4-6}$ The mechanism and category of injury appears to play a role in tourniquet application, with non-indicated tourniquets 3.4 times more likely to be applied to patients with GSWs vs all other injury types. This suggests that the first responder and the immediate responder education should emphasize the importance of clinical findings of life-threatening bleeding regardless of the mechanism of trauma. Soft indications for tourniquet placement (i.e., volume of blood loss at the scene, proximity of injury to a major artery, etc.) were not included as indications for tourniquet placement for the purposes of this study. ${ }^{14}$

While our study did not detect that any one provider type was more likely to apply a non-indicated tourniquet, the larger number of paramedics in relation to the relatively smaller number of other provider types suggests that our study was underpowered to detect a difference. Our study was not designed to detect harm from tourniquets. Additional data collection with long-term follow-up would be likely necessary to further study this outcome.

Prehospital tourniquet use in civilian trauma continues to evolve. While some urge caution, others believe that the potential for mortality benefit outweighs the potential for harm. ${ }^{6,15}$ The practice will likely continue to expand as more in the prehospital community advocate for increased utilization., ${ }^{7,16}$ Our study indicates that data reported before the proliferation of "Stop the Bleed" campaigns likely does not reflect the current situation. As others have proposed, prospective data collection and a collaborative registry are necessary to truly assess the risks and benefits of this practice. ${ }^{6,17}$

\section{Clinical Significance}

Many prehospital tourniquets may not be necessary with uncertain potential for harm.

\section{References}

1. Tien $\mathrm{HC}$, Jung $\mathrm{V}$, et al. An evaluation of tactical combat casualty care interventions in a combat environment. J Am Coll Surg 2008;207: 174-178. DOI: 10.1016/j.jamcollsurg.2008.01.065.

2. Kragh Jr JF, Walters TJ, et al. Survival with emergency tourniquet use to stop bleeding in major limb trauma. Ann Surg 2009;249:1-7. DOI: 10.1097/SLA.0b013e31818842ba.

3. Kragh Jr JF, O'Neill ML, et al. Minor morbidity with emergency tourniquet use to stop bleeding in severe limb trauma: research, history, and reconciling advocates and abolitionists. Mil Med 2011;176:817-823. DOI: 10.7205/milmed-d-10-00417.

4. Scerbo MH, Mumm JP, et al. Safety and appropriateness of tourniquets in 105 civilians. Prehosp Emerg Care 2016;20:712-722. DOI: 10.1080/10903127.2016.1182606.

5. Inaba K, Siboni S, et al. Tourniquet use for civilian extremity trauma. J Trauma Acute Care Surg 2015;79:232-7;quiz 332-333. DOI: 10.1097/ TA.0000000000000747.

6. Kauvar DS, Dubick MA, et al. Systematic review of prehospital tourniquet use in civilian limb trauma. J Trauma Acute Care Surg 2018;84:819-825. DOI: 10.1097/TA.0000000000001826.

7. Ross EM, Redman TT, et al. Stop the bleed: the effect of hemorrhage control education on laypersons' willingness to respond during a traumatic medical emergency. Prehosp Disaster Med 2018;33: 127-132. DOI: 10.1017/S1049023X18000055.

8. Duignan KM, Lamb LC, et al. Tourniquet use in the prehospital setting: are they being used appropriately? Am J Disaster Med 2018;13:37-43. DOI: 10.5055/ajdm.2018.0286.

9. Gupta K, Aggarwal N, et al. Re-emphasizing the importance of tourniquet time: severe myocardial depression following tourniquet deflation. Acta Anaesthesiol Scand 2008;52:873. DOI: 10.1111/j.13996576.2008.01663.x.

10. Randall PE. Medical antishock trousers (MAST): a review. Injury 1986;17:395-398.

11. Mattox K. Medical anti-shock trousers: blind faith, poor judgment and patient jeopardy. Prehosp Disaster Med. Cambridge University Press, 1989; p. 39-41, vol. 4.

12. Roberts I, Blackhall K, et al. Medical anti-shock trousers (pneumatic anti-shock garments) for circulatory support in patients with trauma. Cochrane Database Syst Rev. John Wiley \& Sons, Ltd; 1999; available: https://www.cochranelibrary.com/cdsr/doi/10.1002/14651858. CD001856/abstract

13. Lateef $F$, Kelvin T. Military anti-shock garment: historical relic or a device with unrealized potential? J Emerg Trauma Shock 2008;1: 63-69. DOI: 10.4103/0974-2700.43181.

14. Kragh Jr JF, O'Neill ML, et al. Survey of the indications for use of emergency tourniquets [Internet]. ARMY INST OF SURGICAL RESEARCH FORT SAM HOUSTON TX; 2011. Available: http://www. dtic.mil/docs/citations/ADA618942

15. Scerbo $\mathrm{MH}, \mathrm{Holcomb} \mathrm{JB}$, et al. The trauma center is too late: major limb trauma without a pre-hospital tourniquet has increased death from hemorrhagic shock. J Trauma Acute Care Surg 2017;83:1165-1172. DOI: 10.1097/TA.0000000000001666.

16. Callaway DW, Robertson J, et al. Law enforcement-applied tourniquets: a case series of life-saving interventions. Prehosp Emerg Care 2015;19:320-327. DOI: 10.3109/10903127.2014.964893.

17. Schroll $R$, Smith A, et al. A multi-institutional analysis of prehospital tourniquet use. J Trauma Acute Care Surg 2015;79:10-14; discussion 14. DOI: $10.1097 /$ TA. 0000000000000689 . 


\section{Commentary}

Tourniquets in the Era of "Stop the Bleed"-Are Simple Pressure Maneuvers Being Bypassed for Tourniquets in Non-Arterial Bleeding?

The article by Rothstein and colleagues titled "Tourniquets in the Era of "Stop the Bleed"-Are Simple Pressure Maneuvers Being Bypassed for Tourniquets in Non-arterial Bleeding?" addresses the issue of tourniquet overuse.

This is a timely study considering the increase in the general use of tourniquet in civilian trauma and the current debate surrounding the indications for the use of tourniquets in the prehospital setting. Their findings showed that a prehospital tourniquet was appropriately indicated in only $36.4 \%$ of the cases based on at least one of the following inclusion criteria:

- In-hospital arterial injury diagnosed on exam or imaging.

- Emergency invasive intervention required for arterial injury.

- Patient presenting with a complete extremity amputation.

The authors also showed that although there was no statistically significant difference in the frequency of true arterial injury between blunt and penetrating mechanisms, patients who sustained GSWs treated with prehospital tourniquets were more likely to have an arterial injury compared to all other injury types. Furthermore, their results showed no significant differences between provider types (emergency medical technician, police, emergency department personnel, and bystander) and unindicated tourniquet application. Unfortunately, the study did not address patient complications related to the use of tourniquets. Although the findings of this study call for improvement in the use/indications of tourniquet in civilian trauma, there are important elements to consider when addressing this concern.

Primarily, hemorrhagic shock is the most common cause of preventable death in trauma patients. Thus, expeditious hemorrhage control is of the utmost importance to decrease mortality. Military data suggest that the favorable impact of tourniquet use in extremity injuries is more evident when the tourniquet is applied prior to the onset of shock. The "Stop the Bleed" campaign plays an important role in those efforts. Also, it is important to acknowledge that the precise diagnosis of an actual arterial injury on bleeding patient may be a challenging task in the prehospital arena. Moreover, given the specific nature of civilian firearms, patients can bleed from injuries in multiple body regions, thus concomitant extremity trauma amenable to tourniquet use can become unclear because of compounding shock. Another issue pertaining to civilian trauma is the use of anticoagulant medication. Approximately, 2-3 million people in the United States are on some type of anticoagulant medication every year, augmenting the challenges involved in bleeding control when they become victims of trauma. Finally, as pointed out by the authors of the study, prehospital tourniquet use in civilian trauma continues to evolve. Therefore, initiatives to improve the use of tourniquet should focus on providers most frequently involved in tourniquet placement. Awareness pertaining to simple pressure maneuvers prior to tourniquet application, minimizing tourniquet duration, and the risks of reperfusion injury should be emphasized without discrediting the value of this device.

Joao B. Rezende Neto MD, PhD, FRCSC, FACS

Trauma and Acute Care General Surgery

St. Michael's Hospital

Associate Professor of Surgery

University of Toronto

\section{Comentário}

Torniquetes na era de "parar o sangramento" - Manobras simples como aplicar pressão local estão sendo substituídas pelos torniquetes nas hemorragias não arteriais?

O artigo escrito por Rothstein e colegas intitulado "Torniquetes na era de "parar o sangramento" - Manobras simples como aplicar pressão local estão sendo substituídas pelos torniquetes nas hemorragias não arteriais?" aborda o uso excessivo de torniquetes no trauma. "Tourniquets in the Era of "Stop the Bleed" - Are Simple Pressure Maneuvers Being Bypassed for Tourniquets in Non-Arterial Bleeding?"

Esse é um tema oportuno devido ao aumento na utilização de torniquetes no trauma civil e o debate atual sobre as indicações do uso desse dispositivo no pré-hospitalar. Os resultados desse estudo demonstraram que as indicações para o uso de torniquetes no pré-hospitalar foram consideradas corretas em apenas $36.4 \%$ dos casos analisados pelos autores. Este resultado baseou-se nos seguintes critérios:

- Lesão arterial diagnosticada durante exame físico ou de imagem realizados no ambiente intra-hospitalar.

- Necessidade de algum tipo de procedimento invasivo de emergência para o tratamento de lesão arterial.

- Paciente com amputação traumática de algum membro.

Os autores também demonstraram que embora não houvesse diferença estatisticamente significante na frequência de lesões verdadeiramente arteriais entre mecanismos de trauma penetrantes e contusos, pacientes vítimas de traumatismos por arma de fogo, tratados com torniquetes no pré-hospitalar, apresentaram maior probabilidade de terem sofrido lesão arterial. Além disso, os resultados também demonstraram que não houve diferença no uso desnecessário dos torniquetes entre os profissionais que os aplicaram (paramédicos, policiais, transeuntes). Infelizmente, os autores não avaliaram potenciais complicações decorrentes do uso de torniquetes nesse estudo.

Embora os achados desse estudo demonstrem a necessidade de melhorar as indicações do uso de torniquetes no trauma civil, existem elementos importantes a serem considerados.

Primeiramente, há de se considerar o fato do choque hemorrágico ser a principal causa de morte evitável no trauma. Portanto, o rápido controle da hemorragia é de fundamental importância para reduzir a mortalidade. Dados militares demonstraram que o impacto positivo do uso de torniquetes nos traumatismos de extremidades é mais significativo quando o mesmo é aplicado antes do paciente entrar em choque. Esse objetivo tem sido buscado através da campanha atual na América do Norte denominada "Parar o Sangramento". Igualmente importante, é o fato de que o diagnóstico preciso de uma lesão arterial ou não, é tarefa desafiadora no ambiente préhospitalar. Esse desafio torna-se ainda maior devido às características das lesões penetrantes por arma de fogo no trauma civil, onde múltiplas áreas corporais são atingidas causando hipotensão e dificultando ainda mais a detecção de lesões arteriais capazes de serem tratadas com torniquetes. Outro fator a ser considerado é o uso de medicações anticoagulantes pela população civil. Atualmente, entre 2 a 3 milhões de pessoas nos Estados Unidos utilizam algum tipo de medicação anticoagulante todo ano, aumentando os desafios envolvidos no controle de sangramentos quando essas pessoas tornam-se vítimas de traumatismos. Finalmente, conforme descrito pelos autores do estudo, o uso de torniquetes no pré-hospitalar continua a evoluir no trauma civil. Portanto, iniciativas direcionadas a melhorar o uso desse dispositivo no pré-hospitalar deveriam 
focar primariamente nos profissionais envolvidos na aplicação dos mesmos. Como por exemplo, minimizar o tempo de isquemia para reduzir as complicações decorrentes da reperfusão durante o uso dos torniquetes.

Embora, a simples pressão local sobre algumas lesões possa ser eficaz para conter sangramentos, o valor do torniquete continua sendo inquestionável.
Joao B. Rezende Neto MD, PhD, FRCSC, FACS

Trauma and Acute Care General Surgery

St. Michael's Hospital

Associate Professor of Surgery

University of Toronto 